\title{
Disruptive Innovation in Higher Education: The Professional Doctorate
}

\author{
G. Robinson, Member IACSIT, J. Morgan, and W. Reed, Member IACSIT
}

\begin{abstract}
The new Doctor of Business Administration [DBA] Program at a recognized US University is a disruptive innovation in the field of doctoral education. It is meeting the demand for professional doctoral education as a next step in individual professional development. It is disruptive in several ways. First, the courses and curriculum, face-to-face Residencies and Mentor courserooms are innovative by design. Second, learners are matched with a DBA Mentor, chosen for their expertise and strong interpersonal skills. Third, the dissertation process begins immediately with learners choosing a preliminary topic by end of quarter 1 . One of the unique innovative characteristics is its high touch character achieved through technology. Additional elements of disruptive innovation include; Recognition that online education is an innovative and disruptive force in the delivery of higher education. Design is the new fulcrum for management to achieve its performance goals and the DBA enables the candidate to graduate in 12 quarters or less. The new DBA professional doctorate meets the definition of innovation through three qualities of innovation: 1). An invention, i.e., creation of something entirely new; 2). An improvement, i.e., a refinement of what has been developed; 3 ). The diffusion or adoption of innovation developed elsewhere.
\end{abstract}

Index Terms-Professional doctorate, online education, disruptive innovation.

\section{INTRODUCTION}

This paper examines disruptive innovation in higher education and specifically theincorporation of the professional doctorate. It will provide the context for the changing nature of doctorate education and provide a case study of a DBA degree that has been a disruptive innovation in an online university.

\section{THE CONTEXT}

The United States and, increasingly Europe, face a challenge today. In the face of high unemployment people need the right set of skills to gain employment and to continue powering the innovation and performance of private and public sector organizations. Finding innovative new ways to create the skills needed to sustain an enviable record of new products, services and productivity is the challenge. However, there is a problem. The traditional source of new

Manuscript received June 19, 2014; revised September 10, 2014.

G. Robinson and J. Morgan are with Capella University Minneapolis, MN USA (e-mail: docrobinson@comcast.net, jim@innovationitb.com).

W. Reed is with Remingon College, USA (e-mail: bill.reed@remingtoncollege.edu). skills, the university, is failing to keep pace with need. The reasons are numerous; cost, disappearing endowment in the face of an irregular stock market, and the skill mix being produced. Engineers are needed but the number is declining annually. Other skills such as those in technology are not keeping pace with the market. At the same time knowledge continues to expand and evolve. What was accepted as practice and state of the art previously is no longer adequate for the changing demands of an increasingly changing, globally networked world. The same holds true for higher education.

Higher education in the US is facing its own crisis in responding to the need for more skills. The past half century has been dedicated to expanding access to education but the quality has slipped. Higher education is in need of innovation and not just innovation for the current environment but disruptive education that will change the rules of the game to keep pace with the demands of tomorrow. Doing more of the same is not a viable option.

Online for-profit education is a disruptive innovation. It has transformed access to higher education over the past 20 years, now providing the world with the largest university in the world and a wave of others, public and private, adopting and using the on-line business model. This disruptive innovation is not solely a US phenomenon. Others globally have recognized the potential of this innovation and embraced it, bringing with them their own technology-driven organizations who themselves are driving the innovation of online education. One instructor through an innovative on-line platform taught 100,000 students this year in the new Massive Online Open Course (MOOC) and the number is increasing. Online higher education has changed the rules and will continue to do so. Traditional education is now adopting the online model and it is predicted that by 2014 that half of the courses in the United States will be offered by higher education online. It brings new approaches such as outcome and competency based education. There is much to hope for and much to fear depending on your willingness to embrace innovation. As Christensen, Horn Caldera and Soares comment:

"Disruptive education is the process by which a sector that has previously served only a limited few because its products and services were complicated, expensive and inaccessible, is transformed into one whose products and services are simple, affordable, and convenient and serves many no matter their wealth or expertise" [1].

In the business and management schools of higher education Henry Minzberg [2] sounded the clarion call some 25 years ago questioning the adequacy of the MBA as a 
terminal degree for business professional preparation. Minzberg postulated that the uncertainty and complexity of today's world exceeded the breath of the rational analytical approach currently taken by business schools. Moreover, beyond this individuals perceived that to continue their professional currency advanced skills were needed to differentiate themselves in the marketplace. A next step was needed to fill this void and to increase the currency of professional skills.

\section{DOCTORAL EDUCATION}

Doctorate education is an area that is answering this call for increased professional skills. A review of professional doctorate education reveals two areas in particular that offer new opportunities: the evolvement of professional degrees, particularly in business, but also in other disciplines, and the changing environment for doctorate education. Driving this phenomenon in the business environment, for example, is a need for 2400 [3] new doctorates this year. For example because of an exodus of retiring Accounting professors and professionals in Accounting the American Accounting Association (AAA) and the Accounting Programs Leadership Group (APLG) found that, from 2005 to 2008, the new doctorates will be $50.1 \%$ of what is needed. [4] The situation is even direr for the audit and tax professions where new doctorates will be $77.2 \%$ and $72.9 \%$ short of what is needed [4]. Other professions such as Finance Health Management, Business Intelligence, and Information Technology require new professional certification as well as others yet to develop.

Concurrent with the changing landscape of the business world is the changing landscape of doctoral education. The traditional $\mathrm{PhD}$ degree has long been the preferred brand for doctoral education, anchored in academia, and has focused on research and publishing as its lengua franc. Today's knowledge economy requires more than just academic research. Rather, it requires relevance for societal institutions such as business, healthcare, education and government. Park [5] states that "the traditional $\mathrm{PhD}$ model is now being challenged by a growing diversity of types of doctoral degree, including $\mathrm{PhD}$ by publication, professional Doctorates and New Route PhD". Partially driving this challenge is the need for research that provides evidence for continually improved organizational performance that can provide a competitive advantage to an organization whether it be public or private sector. Further supporting this point is Spriestersback and Henry's [6] remark, albeit dated, that in the US, "the standards of $\mathrm{PhD}$ education remain unexplained and the appropriateness of existing practices in $\mathrm{PhD}$ education largely undemonstrated. This has provided an opportunity for those universities with an entrepreneurial spirit to move from a focus on process to outcomes, from content to competence, in order to ensure their relevance to the world of work and, in the process cease supporting the ivory tower metaphor. Moreover, it provides a basis for expanding the base of industry-government cooperation with the Academy in the pursuit of increased relevance.

The professional doctorate is relatively new and some are not acquainted with it. Some define the professional

\section{doctorate as}

"a program of research and advanced study which enables the candidates to make a significant contribution to knowledge and practice in their professional context, in which the candidate may also contribute more generally to scholarship within a discipline or field of study" (CADDGS, 1998:1) [7].

Person [8] sees the professional doctorate "as a form of professional education in which students are introduced to the professional practice of research and scholarship, with the supervisor responsible for assisting students to become independent practitioners". Scholar-practitioners.

While the PhD is usually tightly shaped to research on an individual discipline that contributes to theory and the body of knowledge, professional doctorates seek to focus on practice, contribute to extending the theoretical base of the particular practice and extend the use of the body of knowledge through practice. In summary the $\mathrm{PhD}$ is a research degree, based on theory that contributes to the body of knowledge while a professional doctorate is a research degree that is based on theory that contributes to the application of the body of knowledge through new or refined practice. As will be described later in this paper, from a research perspective there is no difference in the two degrees, the difference is in application to practice in the workplace.

Other differences that distinguish the $\mathrm{PhD}$ and the professional doctorate are the following:

TABLE I: OTHER DIFFERENCES THAT DistingUISH THE PHD AND THE

\begin{tabular}{|c|c|c|}
\hline \multicolumn{3}{|c|}{ PROFESSIONAL DOCTORATE } \\
\hline Criterion & $P h D$ & Professional Doctorate \\
\hline Overall focus & $\begin{array}{l}\text { The } \\
\text { Academy-Research } \\
\text { and Teaching }\end{array}$ & $\begin{array}{l}\text { The Workplace-practice } \\
\text { and organizational } \\
\text { performance }\end{array}$ \\
\hline Scope & $\begin{array}{l}\text { Generally } \\
\text { individualistic }\end{array}$ & $\begin{array}{l}\text { Cohort or team based } \\
\text { model }\end{array}$ \\
\hline $\begin{array}{l}\text { Research } \\
\text { focus }\end{array}$ & $\begin{array}{l}\text { Research-theory } \\
\text { focus for the } \\
\text { Academy }\end{array}$ & $\begin{array}{l}\text { Research-theory focus for } \\
\text { practice in the workplace }\end{array}$ \\
\hline $\begin{array}{l}\text { Time to } \\
\text { complete }\end{array}$ & $\begin{array}{l}\text { Completion takes } \\
\text { average of } 8 \text { years }\end{array}$ & $\begin{array}{l}\text { Can be completed in 2-4 } \\
\text { years }\end{array}$ \\
\hline Cost & $\begin{array}{l}\text { Cost in US will be } \\
\text { approximately } \\
\$ 100,000\end{array}$ & $\begin{array}{l}\text { Cost in US will be } \\
\text { approximately } \$ 50,000\end{array}$ \\
\hline $\begin{array}{l}\text { Research } \\
\text { methods }\end{array}$ & $\begin{array}{l}\text { Uses traditional } \\
\text { research methods }\end{array}$ & $\begin{array}{l}\text { Uses a variety of } \\
\text { traditional and } \\
\text { non-traditional methods }\end{array}$ \\
\hline Client & $\begin{array}{l}\text { Based on needs of the } \\
\text { Academy }\end{array}$ & $\begin{array}{l}\text { Based on needs of } \\
\text { industry and other } \\
\text { organizations }\end{array}$ \\
\hline $\begin{array}{l}\text { Research } \\
\text { location }\end{array}$ & $\begin{array}{l}\text { Research located in } \\
\text { neutral venue }\end{array}$ & $\begin{array}{l}\text { Research preferably done } \\
\text { in workplace } \\
\text { organizaition }\end{array}$ \\
\hline $\begin{array}{l}\text { Knowledge } \\
\text { use }\end{array}$ & $\begin{array}{l}\text { Primarily research } \\
\text { capacity development } \\
\text { followed by } \\
\text { knowledge creation } \\
\text { and professional } \\
\text { development }\end{array}$ & $\begin{array}{l}\text { Primarily professional } \\
\text { development followed by } \\
\text { research capacity and } \\
\text { knowledge creation }\end{array}$ \\
\hline Quality & Quality is inspected in & Quality is build in \\
\hline Program & Linear program & $\begin{array}{l}\text { Tightly integrated } \\
\text { program }\end{array}$ \\
\hline
\end{tabular}


As Kemp [9] notes, one of the challenges of the professional Doctorate "would be to dispense with the flawed notion that PhD's are original research that add to scholarly knowledge and that the professional doctorate contributes principally to practice". The professional doctorate is an evidence-based degree that contributes to both theory and practice.

Contributing to the specific topic of this paper regarding Professional Doctorates and the specific example of the Doctor of Business Administration (DBA) is that in the UK its popularity is increasing "in response to dissatisfaction in the business sector with the traditional PhD (Bourner, Ruggen-Stevens and Bareham" [10]. In all likelihood this will drive changes in the $\mathrm{PhD}$, although it would be difficult to forecast exactly what they will be. In many instances it would appear that it is a classic case of change where one can expect the status quo $\mathrm{PhD}$ to be resistant to change. One of the most effective ways in driving change is through disruptive innovation, one in which all the rules change.

\section{DISRUPTIVE INNOVATION}

Disruptive innovation is yet another evolvement of innovation. Christensen describes it as "an innovation that makes a complicated and expensive product simpler and cheaper and thereby attracts a new set of customers". [11] He further comments that in order to launch a disruptive innovation you need a technology enabler and a business model innovation. He goes on to state:

A disruptive innovation has a couple key elements or enablers that are particularly salient to the future of higher education. The first is a technology enabler. This allows the innovation, which stars in a simple application and competes first against non-consumption-by serving people who were not able to be served or were not desirable to serve-to be "upward scalable" and improve year over year without replicating the cost structure of the old products and services it gradually replaces [12].

The second element of a disruptive innovation is a business model innovation. Disruptive innovations use new models, which enable organizations to respond to customers at this new lower price point or in a new, far more convenient fashion without extra cost [1]. Interestingly to note however, is that a disruptive innovation dropped into a traditional model does not result in disruptive innovation. It may result in sustaining innovation and contribute to continuous improvement in the traditional model. It will provide incremental improvement but will not result in change that will reshape the organization to meet the needs of the changing population of clients.

\section{CAse Study of DisRuptive Education in a PROFESSIONAL DOCTORATE PROGRAM}

A case study of a new doctoral program at an online university in the US is used. The University has approximately 38,000 students with $23 \%$ in undergraduate studies, $44 \%$ in masters programs and 32\% in Doctoral programs. In the latter Graduate degrees are offered in Psychology, Public Health, Education, Business, Technology and others. This paper focuses on a professional Doctor of Business Administration degree program in the School of Business and Technology. The university is regionally accredited by the Higher Learning Commission of the North Central Association of Colleges and Universities, the same accreditation as all other universities in the area covered by the Higher Learning Commission. The university is a member of two organizations that validate quality and one organization that publically discloses assessment data for courses given at the university.

A diagram of the DBA program used as an example in for this paper is shown below:

Doctor of Business Administration (DBA)

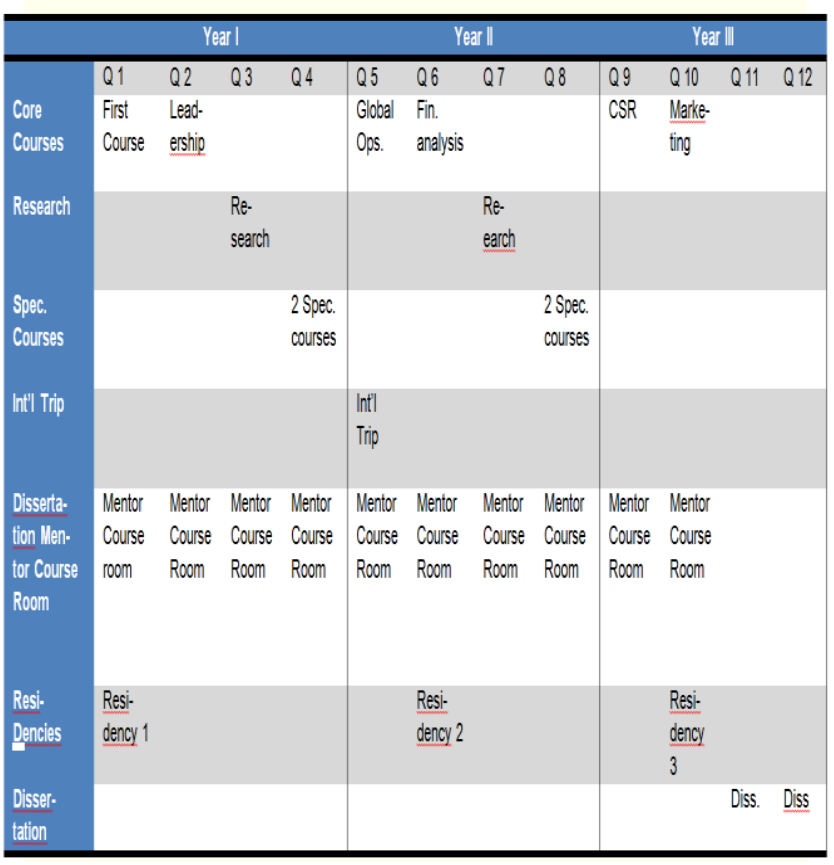

\section{THE DBA PROGRAM AS A DisRUPTIVE INNOVATION AS EXAMINED THROUGH FOUR FACTORS}

\section{A. Test of the Business Model}

A test of the degree to which it applies a new business model, illustrated by the following components of the program. It is based on a comprehensive cost structure for each quarter and includes all costs

1) It contains ten core or specialization courses to ensure capture of knowledge needed for the profession of business

2) There are parallel online residency course and face-to-face residencies

3) The residencies are included in the cost except for travel costs

4) Learners are matched with a DBA Mentor, chosen for their expertise and strong interpersonal skills.

5) Books are provided through e-books, without charge, exceptfor the APA manual which is not offered as an e-book. 
6) Courses and activities are tightly integrated ensuring that all efforts are complementary in a high tech-high touch online environment. It uses the core and specialization courses combined with the the mentor courseroom, the residencies and the International trip to ensure high touch in a high-tech online environment.

7) The dissertation is started in the first quarter and has a structured curriculum for each of the first ten quarters in the mentor courseroom. It takes the mystery out of writing a dissertation and is a dissertation by bytes and bites.

8) It is cost and time effective. The average time for a $\mathrm{PhD}$ degree is 8.1 years and can cost a $\$ 100,000$ or more. The DBA is programed for 3 years at a cost of $\$ 50,000$. Moreover, if learners are particularly adept they may complete the last two courses early thus reducing the cost by $8-16 \%$.

\section{B. Drives Disruptive Innovation}

The DBA drives disruptive innovation by operating quasi-independently and providing a model for other doctoral programs. What other doctoral programs aspire to, the DBA is already doing.

\section{Strategy of Focus}

The focus of the DBA is a core curriculum, delivered in a sequenced (cohort) manner with nine different specializations delivered through four specialization courses. Examples of the specializations are Strategy and Innovation, Business Intelligence, Global Operations and Supply Chain management, Finance, Accounting, Marketing and others. They provide the needed added value for the business professional who needs a higher level of skill to operate in today's competitive market. Research is focused on from an applied perspective of conducting research for the dissertation and advanced Excel tools for data analysis appropriate to the business environment.

\section{Frame Online Learning as a Sustaining Innovation}

Online learning is used as a sustaining innovation and is replete with potential to continue its sustaining character. Sustaining innovations to increase the high-touch quality of the program are being implemented, including Sharepoint and others.

As one contemplates sustaining innovation, consider the multitude of new platforms that are emerging. The latest being Coursera by two professors at Stanford University where one states that he has taught 100,000 students this year using the platform. Granted that these courses do not carry credit, but they only cost $\$ 100$ and Stanford gives a certificate documenting that the course was taken and passed.

\section{INNOVATION THROUGH A DIFFERENT LENS}

Innovation may also viewed through another frame and that is the degree to which it adheres to three qualities of innovation [13]:

1) An invention, i.e., creation of something entirely new.

This would be the correlary to disruptive innovation.

Something new that sets new rules of the game.
2) The DBA is inventive from the aspect of something entirely new by beginning the dissertation in the first quarter, and providing learners with a comprehensive strategy and unique resources to complete the dissertation in 12 quarters.

3) An improvement, i.e., a refinement of what has been developed; this fits the definition of sustaining innovation. While this is simply improvement of the current business model, it is an improvement from the perspective that it uses online education but in a novel design.

4) The DBA is an improvement of both online higher education and doctoral education.

5) It is the result of diffusion or adoption of innovation developed elsewhere and adapted and adopted through the application of competencies and outcomes pedagogy.

6) The DBA builds upon innovations in other universities but creates a new model.

7) For education to be relevant, it must operate on the basis of outcomes and competencies.

8) The DBA is an outcomes and competency based model

\section{REFERENCES}

[1] C. H. Caldera and Soares. (2011). Disrupting college: How disruptive innovation can deliver quality and affordability to postsecondary education. [Online]. Available: www.American progress.org and www.innosightinstitute.org.

[2] H. Mintzberg, Mintzberg on Management: Inside Our Strange World of Organizations, New York: Freepress, 1989.

[3] Damast and Alison, "Business PhD applications on the rise," Bloomberg Business Week, May 11, 2009

[4] T. Noland, B. Francisco, and D. Sinclair. (2007). Pursuing a PhD in Accounting, What to expect. [Online]. Available: www.cpajournal.co.

[5] C. Park, "New Variant PhD: The changing nature of the doctorate in the UK," Journal of higher Education Policy and Management, vol. 27, no. 2, p. 190, July 2005.

[6] D. Spriestersback and L. Henry, "Improving college and university teaching," The Ph.D dissertation: Swrvantor master, vol. 26, no. 1, pp $52-55,1978$

[7] T. Evans, A. Fisher, and W. Gritching, "Council of deans and directors of graduate studies 1998," Professional doctorates.

[8] M. Person and L. Ford, "Open and flexible PhD study and research," Report 97/16, Evaluations and Investigations Progream, Higher Education Division, DETYA, Canberra, 1997.

[9] S. Kemp, "Professional doctorates and doctoral education," International Journal of Organizational Behavior, vol. 7, no. 4, p. 404 , 2004.

[10] T. Bourner, G. Ruggen-Stevens, and J. Bareham, "The BDA: form and function," Education + Training, vol. 42, no. 5, pp. 481-95, 2000.

[11] C. Christensen, "Disruptive innovation and catalytic change in higher education," in Proc. Forum for the Future of Higher Eduation, 2008, p. 43.

[12] C. Christensen. (2011). Disrupting college: How disruptive innovation can deliver quality and affordability to postsecondary education. [Online]. pp. 2. Available: www.american progress.org/issues/2011/02

[13] L. Zhuang, D. Williamson, and M. Carter, "Innovate or liquidate - are all organisations convinced? A two-phased study into the innovation process," Management Decision, vol. 37, issue 1, p. 57, 1999.

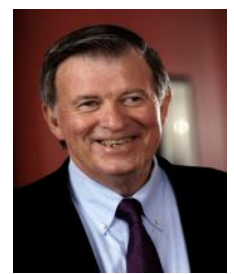

Gary D. Robinson held a $\mathrm{PhD}$ degree in organizational behavior from Case Western Reserve University in Cleveland in Ohio, USA, in 1977. He was an acting dean of Forbes education in 2013-2014 and was the chair of leadership and general business at Capella University from 2005 to 2013 . He is a professor in the School of Business and Technology at Capella University in Minneapolis, MN USA. He is also an associate at the International Institute for Child Rights and Development. His has several publications, such as K. Blum, B. Muirhead et al., "Conquering the mountain: framework for successful chair advising of online dissertation 
students," International Journal of Instructional Technology \& Distance Learning, 2005.

Dr. Robinson is a member of the Academy of Managementand a reviewer for the African Journal of Management, and Routledge, Ltd.

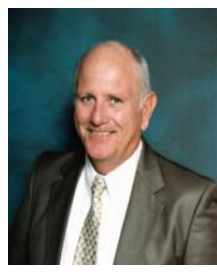

William Reed completed his Ph.D. in management performance and leadership at the Union Institute and University in Cincinnati, Ohio, USA. Dr. Reed's academic background closely compliments his business and management experience. Dr. Reed has held numerous academic appointments including the dean and the chair. He is presently the chair of Business at Remington College.

Dr. Reed began his working career as a corporate pilot, with captain type ratings in Lear Jet, serving executive clients throughout the U.S., Caribbean, Canada, and Mexico. He worked with the FAA as an air traffic controller in Chicago and New York. In 1981, He entered the business world, owning numerous businesses and organizations. After 17 years of self-employment, Dr. Reed entered the corporate environment where he was active in senior management for almost 9 years. He was the executive director of sales for a division of a $\$ 2.5$ billion sales organization. Dr. Reed has published several books on leadership. Dr Reed is a member of the Academy of Management.

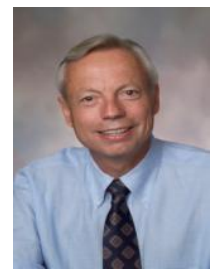

James Morgan completed his $\mathrm{PhD}$ degree in organization and Management in 2003 at Capella University in Cincinnati, Ohio, USA. He is also a CPA, $\mathrm{CFA}$, and $\mathrm{CPCU}$

$\mathrm{He}$ is presently the core faculty and lead for strategy and innovation in the School of Business and Technology at Capella University in Minneapolis, MN USA. He has had a varied career as an accountant, insurance executive, consultant, and professor. Dr. Morgan is a member of the Academy of Management. 